\title{
Are SMEs Efficient? Applied Study on the SMEs Financed by Islamic Banks in Jordan
}

\author{
Iyad A. Al-Nsour \\ Prof. Dr Sa'dun N. Al-Hiti \\ AL-Madinah International University, Malaysia
}

\begin{abstract}
This study aimed at measuring the role of Islamic banks (IB) in Developing small and medium enterprises (SMEs) in Jordan, by measuring the efficiency level of such enterprises. The study population consisted of all small and medium enterprises SMEs funded by Islamic Banks IB operating in Jordan for 2016, which estimated at (3207) enterprises. The full survey method was used. The study found that there was a weak role of Islamic banks in developing small and medium enterprises in Jordan. This study showed that SMEs financed by Islamic banks showed that SMEs funded by Islamic banks (IB) have achieved the lowest economic efficiency compared to those financed by other microcredit sources operating in the economy. Finally, The study recommended and suggested some implications that enhance the role of Islamic microfinance in developing the SMEs sector in Economy of Jordan .
\end{abstract}

Keywords: SMEs , Efficiency, Islamic Banks, Jordan.

DOI: $10.7176 / \mathrm{EJBM} / 11-4-02$

\section{Introduction:}

Islamic Microfinance institutions differ from formal financial institutions in their target customers, in their seeking to get certain financial services with their inability to supply financial or non-financial collateral (Siddiqui, 2008). There is no doubt both, microfinance and Islamic finance complement one another. Islamic finance's emphases on entrepreneurship, materiality, and risk sharing are reflected in microfinance's basic model of joint-liability lending to the entrepreneurial poor with low income both men and women. Traditional thought that aren't encouraged by today's conventional financial services industry in their common pursuit to achieve comprehensive development for society (Karim, Michael, and Xavier ,2008; Siddiqui, 2002). The experiment of the social bank in the Egyptian village of MitGhamr in1963 is important evidence on this entrepreneurial orientation.

There is no doubt that microfinance eliminated poverty, empowered women and enhanced education and health (Wrenn, 2007, p.4). In addition, it improved clients income earning capacity, built their asset portfolio and reduced client susceptibility, with positive effects on poverty alleviation schemes in the countries which adopted this model (Wrenn,2007, p.5). On the economic level Microfinance also promotes consumption smoothening, economic growth and financial deepening (MOF, 2015).

The microfinance movement began in the 1970s, as an experimental program in Bangladesh in which groups of poor women with no collateral were extended small loans from a state funded NGO to invest in productive activities. In place of collateral, "group solidarity" also referred to as "joint-liability" was used to guarantee repayment of the loans, which were made at high, but not unfeasible interest rates (Rezaul and Osada, 1998).

All these procedures contributed to the development of the concept of microfinance. Many traditional financial institutions and some governmental institutions have been quick to adopt the microfinance strategy. The experience of Grameen Bank in Bangladesh is one of the leading models in this field all over the world (Awojobi \& Bein, 2011).

And in a related manner, Islamic microfinance in its framework could help improve the standard of living of low-income earners and the poor because it discourages exploitation and achieves an objective of social justice. Islamic microfinance represents the confluence of two rapidly growing industries: microfinance and Islamic finance It has addresses the unmet microcredit demands and also satisfies the Islamic social principle of caring for the less fortunate with microfinance's power to provide financial access to the poor (Karim et al., 2008).

That was not to be achieved without a number of key Shari'a principles which distinguish Islamic finance from the conventional forms. These principles have led to the creation of a separate finance industry are the prohibition on usury and interest (riba), prohibition on realising a gain from speculation (mayseer), absence of uncertainty in commercial transactions(gharar), in addition to the requirement that all activity must be for permitted purposes (halal) (Onakoya \& Onakoya, 2013).

Finally, we say that Islamic microfinance will play a vital role to cut poverty by 2015 , microfinance was claimed to reach 175 million of the poorest families (Wrenn, 2007, p. 2), all over Islamic world and the countries which adopted this strategy. Data shows that microfinance growth is increasing in Indonesia, Bangladesh and 
Afghanistan; however, it is clearly weak in the Middle East markets (Frasca, 2008).

Microfinance has successfully opened economic opportunities improving the social economic condition of the poor, which attests to the fact that microfinance reduces poverty through accelerated employment rate and increase in real wages (Awojobi \& Bein, 2011). Islamic finance also helped in the growth of real economic activities which creates value for financial activities. In this light, there will be creation of more jobs, which will have a positive impact on unemployment and a greater long term effect on sustainable development of the economy (Siddiqui, 2002).

\section{Literatures Review:}

Most of studies, especially those dealing with Islamic finance, aimed at finding out the impact of this financing on a set of macroeconomic variables ,particularly the rate of economic growth, the volume of domestic investment and the inflation rate. The results of these studies have confirmed the positive and strong impact of Islamic finance in promoting growth in local economies (Al-Omar and Iqbal, 2000).

Other studies have examined the impact of financial constraints on small enterprises, and found that these constraints have clearly affected the profitability of SMEs and have clearly reduced them. Other studies have also examined the impact of Islamic banking on the entrepreneurial motivation, competitiveness and performance of small enterprises. These studies have confirmed the positive impact of the Islamic banking on both the entrepreneurial motivation and the level of competitiveness of the small enterprise, while it is clear that Islamic banking does not affect small enterprises.

For instance, the Study of Fawwaz, Alawneh and Shawaqfeh (2015) shows a statistically significant positive relationship between Islamic finance and GDP, domestic investment, and economic growth. This means that the Islamic finance contributes significantly to the promotion of the economic activity and it supports the process of economic development. The study confirmed that the statistical significant negative correlation between Islamic finance and inflation rate which that the Islamic finance enhances the production of goods and services in the economy field leading to a decline in the general price level. All of above result have confirms by the study of Imam and Kpodar (2015), which has shown that Islamic banking is positively associated with economic growth even after controlling for various determinants, including the level of financial depth. But the report of bank of international settlements (2014) shows that start-ups which report finance as their greatest constraint receive smaller new loans and evidence that financing constraints reduce start-up profitability. We do not find a similar relationship for older SMEs in pre-crisis data. Therefore, policy initiatives which ease financing constraints for start-ups could play an important role in boosting economic growth. However, following the protracted financial crisis in Europe, we also find that financial constraints reduced profitability in the cohort.

In 2014 a study by group of researchers Oqool, Okab and Bashayreh (2014) showed that there is bidirectional long-run Granger causality between real GDP and FINC (financial Islamic banking development) reflecting a positive contribution of Jordanian Islamic banks in financing the process of Jordanian social and economic development. The relation appears to be unidirectional relation between real GDP and DEPT running from real GDP to DEPT reflects the excess liquidity problem that all Jordanian Islamic banks suffer from it. With regarding to short-run causality there isn't any significant relations between FIBD and EG.

The study of Hove, Sibanda and Pooe (2014) adds that Islamic banking has a positive impact on both entrepreneurial motivation and firm competitiveness while the relationship between entrepreneurial motivation and the business performance of SMEs was found not to be significant. Furthermore, the study found that firm competitiveness has a highly significant and strongly positive impact on business performance of SMEs. In view of these findings, the paper concludes with some implications and policy recommendations for both the banks and the government.

By the same token, the study of Sarwer, Ramzan and Ahmad (2013) showed that that Islamic banking in Pakistan had positive impact on economic development. Some scholars around the world consider the use of Islamic banking more convenient for economic development. This result also indicates that improving the infrastructure of Islamic finance in Pakistan could benefit economic development. Islamic banks can play an important role in Pakistan today.

The study of Moruf in 2013 showed the positive and significant relationship between microcredit delivery service and SMEs performance. However most micro finance businesses seem to be competing with the commercial banks in universal banking rather than the microfinance banking they were purposely established to undertake. This manifested in the hesitation of credit to SMEs for fear of repayment. We can say also, according to Onakoya and Onakoya (2013), that Islamic microfinance in concert with the right fiscal and monetary policies framework, will contribute positively to poverty alleviation in Nigeria.

Consequently, The study of Abdullah and Manan in 2011 revealed that start up SMEs do not require much external funding for set up, and besides they are commonly deficient of the means to obtain added funds. As SMEs grow and expand, the need for additional fund will arise, thus the external financial needs will start to 
increase even though the internal funds represent a significant proportion of their available funds. Among the SMEs that have obtained external finance, the amount and tenure of the funds tend to be small and short to medium terms respectively. The finding indicated that the age and assets of SMEs are insignificantly correlated to their accessibility to finance. Thus, the study concludes that a wide variety of financial facilities provided by various agencies and financial institutions lead to greater accessibility to finance SMEs in the country.

There is no doubt that the previous studies have shown the importance of Islamic finance in developing and improving SMEs and seeing it as an effective strategy in achieving growth and development, and its ability to absorb labor supply and creating new opportunities for Job seekers and increasing the incomes, and here (Santos, 2009) shows that SMEs are considered sustainable solutions that are reflected positively on the economic growth. But the study of Johnson (2013) showed that Islamic banks are not significantly correlated with economic growth. Most notably, including the Islamic banking instrument affects the strength of beta-convergence.

Finally, we note that there are a lot of studies that linked the Islamic finance concept to many variables, we find that study of khathlan and Nsour (2011) concludes that the small services enterprises which were funded by development and employment fund have achieved an economic efficiency exceeded what other enterprises have achieved. The results showed also that the small funded agricultural enterprises are more labor intensive while other small funded enterprises are more capital intensive. Furthermore, while the small funded services enterprise achieved higher average total productivity, the study shows that the changes in cost of capital and cost of labor in most of small enterprises that have been funded by DEF are positively related to these changes, but the tourism small funded enterprises are excluded.

Generally, a lot of studies have tried to find and identify the impact and the relationship between the concept of Islamic finance, and a lot of economic indicators, and some studies differed in reaching an agreed about outcome. According to the concept of Islamic microfinance still there are a limited number of those studies that have tried to search what this concept and its association with certain variables, which is considered an important justification for conducting this study.

\section{Hypotheses:}

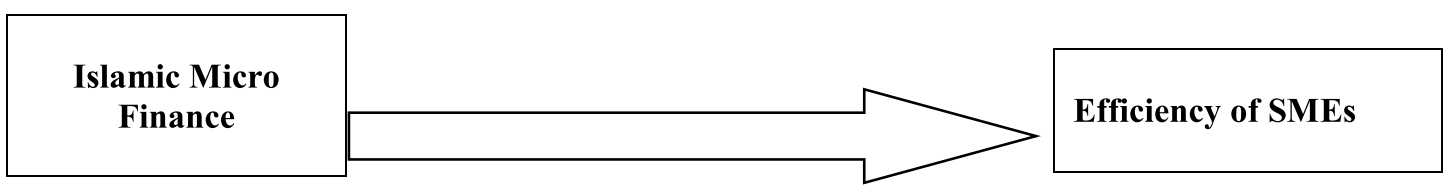

The development of the hypotheses is done in the light of literature and economic theory. They are as under: H1 : The efficiency level (economic and technical) of SMEs financed by Islamic Banks is higher than the level of SMEs financed by microfinance institutions in Jordan.

\section{Reseacrh Methodology:}

This study, using econometric economic models, attempts to identify the effect of the financing granted to small and medium enterprises by the Islamic banks operating in Jordan on level of efficiency in these enterprises. Therefore, the analysis unit in this study represents all the small and medium-sized enterprises that are financed by the Islamic banks operating in Jordan during 2016 according to the data of the General Administration of Loans in those banks. The research Population consists of all small and medium-sized enterprises, which received funding from the four Islamic banks operating in Jordan, which are included in this study for 2016.

In this study, we have used the method of surveying for all small and medium-sized enterprises financed by Islamic banks operating in Jordan : Jordan Islamic Bank, Arab, Islamic International Arab Bank, SAFWA Islamic Bank. A pilot study was conducted. The data collection methods are usually different according to the data collected. Primary data, for example, are original and collected for the purpose of the study. Secondary data provide a broader cover for the general framework of the study.

The methods which are used to collect primary data are interview and questionnaire, all of which supplement the lack of secondary data or its deficiency on achieving the objectives of the study. The questionnaire is handled to the respondent to answer, while the interview is one of the communication tools through which questions are directed to the respondent.

\section{Farrell Model for Economic Efficiency:}

It is difficult to make real and direct comparisons between small projects funded by Islamic banks operating in Jordan to find out which ones are more efficient in using productive resources. This is because such direct comparisons require one level of infrastructure services for these projects. The prices of the production factors are supposed to be equal for each one, especially the price of the labor factor. The comparison process is also more difficult if it is conducted on institutions belonging to different productive sectors. 
The total or partial absence of these conditions makes the direct comparison process questionable, and may result in erroneous conclusions. Therefore it is impossible to conduct such direct comparisons to determine the efficiency of the funded SMEs. For this reason, we will try to rely on indirect standards on measuring economic efficiency. Specifically, "Farrell" Social standard, which uses the social cost indicators of production inputs (capital and labor).

According to Farrell's concept, an enterprise can be classified as efficient if it can achieve the lowest level of average cost per unit produced. This is done only by using a mixture of production factors, so that the cost of one unit is as low as possible. The Farrell standard of efficiency can be expressed as follows:

\section{Whereas:}

$$
\text { Minimum (rk + WI) / Q ) }
$$

- $\quad$ r: Represents the interest rate on which SMEs loans are granted by Islamic banks under stud.

- $\quad$ w: Average real wage per worker in the funded SMEs .

- $\quad$ K: Capital granted in J.D.

- $\quad$ L: Number of workers.

- Q: Amount of production or value added of small and medium enterprises financed by Islamic banks under study.

This Index assumes the following:

1. Full competition in the production factors market.

2. The project that achieves the minimum average cost of production is economically more efficient than other projects.

3. All funded projects face a different price for capital (the weighted average interest rate on which the Islamic banks grant their loans).

4. The average wage of the worker in each project equals the marginal productivity value of this factor.

\section{Testing The Hypothesis}

This estimation process will be done by source of SME funding.

The following table (1) shows how the Farrell index is calculated taking into account the average annual actual worker wage, and using Farrell formula.

Table 1: Farrell index for SME efficiency according to funding source for 2016.

\begin{tabular}{lccccccc}
\hline \multicolumn{2}{c}{ MEs Type } & r \% & K & L & W & VA & Farrell \\
\hline SMEs Financed By Islamic Banks & 6.71227 & 218360000 & 4170 & 6309 & 15687928 & $\mathbf{0 . 2 6 1 1}$ \\
SMEs Financed By Specialized & 5 & 45856952 & 15182 & 5978 & 35685659 & $\mathbf{2 . 6 0 8}$ \\
Institutions & & & & & & \\
Total SMEs Operating In The Economy & 7.8 & 594944566 & 548455 & 6119 & 4629166878 & $\mathbf{0 . 7 3 5 6}$ \\
Large enterprises & Operating In The & 8.6 & 2039818954 & 1376588 & 6119 & 12897316550 & $\mathbf{0 . 6 6 6 7}$
\end{tabular}

Economy

The previous table shows that SMEs financed by Islamic banks achieved higher economic efficiency, compared to other SMEs funded by sources. SMEs were financed by Islamic banks under study need JD (0.26) as the cost of labor and capital factors to create one JD of value added, while SMEs financed by specialized lending institutions need JD 2.6 to create or generate one JD of value added. SMEs operating in the economy as a whole were found to be less efficient than SMEs financed by the Islamic banks under study according to the Farrell index, and also by the large enterprises in the economy. Islamic banks separately recorded convergent values in the Farrell index. SMEs financed by the Jordan Islamic Bank (0.22) is more efficient compared to SMEs financed by Islamic International Arab Bank and SAFWA International Bank. In general, SMEs funded by Jordan Islamic Bank need a cost for their production factors, lower than those financed by Islamic International Arab bank or AWFWA bank, with the aim of generating one JD of value added.

Researcher RosKamp has pointed out that the average of the actual wage of a worker may not necessarily reflect the hypothesis of parity with its marginal productivity. Instead, he suggested calculating the real wage that reflects the marginal productivity of labor factor. To achieve this, RosKamp has used the following equation to determine the wage that reflects the marginal productivity of the labor factor.

$W^{*}=(\mathbf{V} / \mathbf{L})-\mathbf{m}(\mathbf{K} / \mathbf{L})$. This formula is used to calculate the real wage which reflects the marginal productivity of the labor factor, after estimating the value of the coefficient (C) of the relationship $\left(\mathbf{V} / \mathbf{L}=A W^{b}(K / L)^{c}\right)$. In its logarithmic formula, which was used in turn to calculate the value of $(\mathrm{m})$. 
Table 2: Estimation results of $V / L=A W^{b}(K / L)^{c}$ and statistical indicators.

\begin{tabular}{|c|c|c|c|c|c|}
\hline SMEs Type & Value A & Value b & Value c & Value $\mathbf{m}$ & statistical indicators \\
\hline SMEs Financed & 6.615 & -0.328 & -0.17 & -0.243708 & $\mathrm{r}=0.753 \quad \mathrm{R}^{-2}=0.422$ \\
\hline Islamic Banks & $(3.219)$ & $(-2.357)$ & $(-0.481)$ & & $F=3.925 \quad$ Siq. $=0.81$ \\
\hline & 0.018 & 0.057 & 0.648 & & $t^{*}=1.895$ \\
\hline SMEs Financed & 0.17 & 0.028 & 0.732 & 0.963139 & $r=0.839 \quad R^{-2}=0.605$ \\
\hline Specialized & $(0.937)$ & $(0.241)$ & $(2.737)$ & & $F=7.117$ Siq. $=0.026$ \\
\hline Institutions & 0.385 & 0.817 & 0.034 & & $t^{*}=1.895$ \\
\hline SMEs & 1.025 & 0.726 & 0.054 & 0.00069462 & $r=0.966 \quad R^{-2}=0.912$ \\
\hline Operating & (3.253) & $(6.931)$ & $(0.798)$ & & $F=42.274$ Siq. $=0.0$ \\
\hline Economy & 0.17 & 0.0 & 0.455 & & $t^{*}=1.895$ \\
\hline enterprises & 0.799 & 0.637 & 0.239 & 0.0378 & $\mathrm{r}=0.972 \quad R^{-2}=0.925$ \\
\hline Operating In The & (1.787) & (4.104) & $(3.358)$ & & $F=50.609$ Siq. $=0.0 .0$ \\
\hline Economy & 0.124 & 0.006 & 0.015 & & $t^{*}=1.895$ \\
\hline
\end{tabular}

$* t$ values between brackets indicate the value of the test.

* A represents the estimate of the constant term (logarithm A).

* All $t$ values at 0.05 significance level

* $\mathbf{t}^{*}$ Represents the tabulated values.

The previous table shows the results of the estimation, after the logarithmic adjustment and the assumption of the necessary conditions for applying the method of the Ordinary least squares (OLS), using the estimate of (c), the value of $(\mathrm{m})$ is calculated through the relationship $\left(W^{*}=(\mathrm{V} / \mathrm{L})-\mathrm{m}(\mathrm{K} / \mathrm{L})\right)$ results indicate that the wage factor (through the value of "b") is considered an ineffective factor according to the worker's productivity of value added (the share of the worker in value added) in SMEs financed by Islamic banks, and even specialized lending institutions, while it's statistically effective on the productivity of the worker in terms of added value in total SMEs as well as in the total projects operating in the economy. That result is shown by the value of test (1.895) for all other types of SMEs operating in the economy.

Table 3:Actual and calculated average wage for 2016 in JD.

\begin{tabular}{lccc}
\hline SMEs Type & Average actual wage & Average real wage & Actual / Real \% \\
\hline SMEs Financed By Islamic Banks & 6309 & 53340.2 & $\mathbf{1 1 . 8}$ \\
SMEs By Financed Specialized Institutions & 5978 & 8985 & $\mathbf{6 6 . 5}$ \\
Total SMEs Operating In The Economy & 6119 & 8432.3 & $\mathbf{7 2 . 6}$ \\
Large enterprises Operating In The Economy & 6119 & 9137.8 & $\mathbf{6 7}$ \\
\hline
\end{tabular}

The share of the worker in the capital of SMEs financed by the Islamic banks under study is considered an ineffective factor on the productivity of the worker in terms of value added, while this variable was a statistical factor in the SMEs financed by governmental specialized lending institutions, as well as in the total SMEs of the economy, and even projects of all sizes operating in the economy.

Based on table (3), the real wage reflecting marginal productivity is calculated. The table indicates that the percentage of the actual wage obtained by the worker in SMEs financed by the Islamic banks under study, formed a small percentage of the real wage, which reflects the marginal productivity of the labor factor which reached $11.8 \%$ compared with the rest of SMEs financed by other sources. There is a clear reduction in the productivity of the worker in SMEs funded by the specialized lending institutions and also in the total of SMEs operating in the economy as a whole.

In general, we conclude that SMEs financed by Islamic banks in Jordan are not isolated from distortions (wage structure and structure of interest rates) in the markets of production factors, which are in favor of private financial institutions and commercial banks and because of these distortions, Farrell index of economic efficiency, takes the following formula to become a standard for the social efficiency of production (it uses the wage level and interest rate, which reflects the marginal productivity of labor and capital factors respectively.)

\section{Minimum $\boldsymbol{r}^{*} \mathbf{K}+\boldsymbol{W}^{*} \mathbf{L} / \mathbf{Q}$}

In order to apply this standard on SMEs financed by the Islamic banks under study and their counterparts funded by other sources under comparison, we use the real wages calculated in table (3) as an approximate indicator of the social cost of the labor factor. The interest rate that reflects the social cost of the capital factor is the weighted average on which SMEs financed by the Islamic banks under study, and other sources under comparison, as shown in table (2), by using value added rather than production volume and available data for 2016 , the results of this standard are shown in table (4). 
Table 4. :Results of the Farrell standard using the average of real wage for 2016.

\section{SMEs Type}

SMEs Financed By Islamic Banks

SMEs Financed By Specialized Institutions

Total SMEs Operating In The Economy

Large enterprises Operating In The Economy

The last table shows that SMEs financed by the Islamic banks achieved the lowest economic efficiency level compared to the SMEs funded by other sources, and this result is different from the hypothesis which says that SMEs financed by such banks are economically more efficient. Generating one JD of value added in SMEs financed by Islamic banks requires J.D (10.8) as the cost of the prices of production factors, and it's higher than those required by SMEs funded by specialized sources (3.89) and even those funded by various sources operating in the economy, which achieved the lowest level of cost reached almost one J.D. This means that SMEs which receive financing from other sources in the economy (except Islamic banks) are economically more efficient in generating output as measured by value added. This result is contrary to the third hypothesis.

The contradiction between the hypothesis and the result is due to the high cost of the labor factor represented in the real wage in SMEs financed by Islamic banks compared to those funded from other sources, and this is consistent with the data obtained from Islamic banks under study, which showed that the cost of one worker in SMEs financed from those banks up to JD (38) thousand, and at a time this cost reaches less than JD 2,500 in the specialized lending institutions, not to mention the concentration of SMEs funded by those banks in the capital-intensive industrial sectors, and moving away from their ability to run workers and absorb their surplus.

\section{The Discussion and Conclusions:}

In this research we find that the percentage of small enterprises operating in the economy, according to the statistics of 2016 is about $(70.7 \%)$ of the total enterprises operating in the economy, while the value added reached only ( $35.9 \%$ ) of the total value added of the economy as a whole. These enterprises also contributed to the employment of $(39.8 \%)$ of the total labor force in the whole of economy.

According to the SMEs financed by the Islamic banks under study in 2016, they amounted to about $(1.77 \%)$ of the total number of small enterprises operating in the economy. They also contributed about $(0.76 \%)$ a new job opportunities, or $(0.3 \%)$ of the total job opportunities generated by the economy as a whole, and the returns of workers in these enterprises reached about JD (26.3) million for the year 2016 too.

The results of our current study, after calculating the real average wage, which reflects the marginal productivity of the labor factor of SMEs financed by Islamic banks, showed that these enterprises achieved the lowest economic efficiency compared to those financed by other microfinance sources operating in the economy. Here, we see that generating one JD of the value added in SMEs financed by the Islamic banks needs a higher cost of purchasing factors of production represented by labor and capital. The results showed that the high cost of the labor factor represented by the real wage explains the main reason for the increase in the total cost.

At a time when the cost of one worker in SMEs financed by Islamic banks amounted to JD 38,000, it reached JD 2500 in SMEs financed by specialized institutions, while as the focus of those financed by Islamic banks in capital intensive sectors and requires technology and capital equipment with high cost, which reduces its ability to employ workers and absorb the surplus of labor.

The results of the studies do not differ with the results of our current study in saying that the SMEs in a number of countries in the world have achieved the highest efficiency compared to their counterparts, (Page \& Steel, 1984) have found that capital intensive large institutions work at low levels in the exploitation of production materials available and this result indicated by the studies by (Bani Hani \& Shamia, 1989) and a study by (Khrabsha \& Malkawi, 1988), these studies see that the large projects that have more than 20 workers recorded volatile and declining transactions of marginal productivity and unable to exploit the capacity of production available. In this study we found that the SMEs financed by Islamic banks under study are decreasing in returns to scale or the productivity of production factors, but SMEs funded by the specialized lending institutions are increased.

Therefore, the efficiency of SMEs operating in Jordan are linked mainly to the source of funding and the extent of the decline or decrease in the level of distortions in wage structures and interest rates in the markets of production factors, and that reflects on the improvement of levels of efficiency in the exploitation of production factors in those projects and according to available data, these distortions are usually in favor of national financing institutions and commercial banks operating in the economy as they have interest rates reflecting the social cost of capital and they provide projects capable of granting wages that reflect marginal productivity of labor factor.

From this point, we find that small enterprises operating in Jordan are less efficient than the rest of the categories of projects operating in the economy. It has been shown that creating one dinar of value added in 
SMEs operating in the Jordanian economy requires JD (5.2) as a cost of production factors (labor and capital) without looking at the source of funding, while we find that this cost reached less than one dinar (0.89)in the categories of projects Operating in the economy, most of which were large in size and mostly financed by commercial banks.

Based on the previous findings, the study recommends that there is a necessity to change the structure of SMEs on funding from specialized financial institutions (governmental) to depend on Islamic and commercial banks as a major source of financing the economic development in Jordan. The banks should establish joint units to provide microfinance to their customers and the government should also provide the required facilities to qualify and train microfinance applicants in the fields and sectors needed by the economy. In addition, the Jordan investment board should be tasked to cooperate with relevant local authorities to develop awareness and guidance roles in the local economy in order to identify the horizons of SMEs in Jordan and to address other local authorities such as the Municipal Councils.

\section{References}

- Abdullah, M., and Ab, Manan. (2011). Small and medium enterprises and their financing patterns: Evidence from Malaysia. Journal of Economic Cooperation and Development, 32(2).

- Alawneh, M., Al-Fawwazm,T., and Shawaqfeh, G. (2015). The Impact of the Fiscal and Quantitative Monetary Policies on the Domestic and Foreign Direct Investment in Jordan: An Empirical Study. International Journal of Academic Research in Accounting, Finance and Management Sciences,5(4).

- Al-Omar, Fuad., and Iqbal, Munawar. (2000). Some Strategic Suggestions for Islamic Banking in 21st Century. Review of Islamic Economics, 9.

- Awojobi, A., and Bein, M.A. (2011). Micro financing for poverty reduction and economic development: A case for Nigeria. Inter. Res. Journal of Finance and Economics.

- $\quad$ Bani Hani., A, and Shamia, A. (1989).The Jordanian Industrial Sector: Output \& Productivity 1967-1986 : An Economic Analysis. Abhath Al-Yarmouk, 5(2).

- Bank of international settlements, (2014).Annual Report. Switzerland.

- Farrell, M. J. (1957). The Measurement of Productive Efficiency, Journal of the Royal Statistical Society, 120.

- Frasca, Alexandra (2008). A Further Niche Market: Islamic Microfinance in the Middle East and North Africa.

- Hove, P., Sibanda, K., and Pooe, D. (2014). The Impact of Islamic Banking on Entrepreneurial Motivation, Firm Competitiveness and Performance in South African Small and Medium Enterprises. Meditation Journal of Social Sciences, 5(15).

- Imam, Patrick., and Kangni, Kpodar. (2010). Islamic Banking: How Has it Diffused, IMF Working Paper, 10(195).

- Johnson, K. (2013).The Role of Islamic Banking in Economic Growth. CMC Senior Theses. http://scholarship.claremont.edu/cmc theses/642.

- Johnson, R., and Soenen, L. (2003). Indicators of successful companies. European Management Journal, 21(3).

- $\quad$ Karim, N., Michael, T., and Xavier, R. (2008). Islamic Microfinance: An Emerging Market Niche. Report. CGAP.

- Khrabsha, A., and Malkawi, A. (1988). The Productivity in Industrial Firms which employ More Than 20 workers. Dirasat Journal, 15(2).

- Khthlan, K., and Nsour, I. (2010). Estimating The Efficiency of Small Enterprises That Funded From Development \& Employment Fund In Jordan. Dirasat Journal for managerial Sciences, 37(2).

- $\quad$ Ministry of Finance (2015). Annual figures . Amman.

- Moruf, O. (2013). Evaluation of the Nigerian Microfinance Banks Credit Administration on Small and Medium Scale Enterprises Operations. International Review of Management and Business Research, 2(2).

- Omar, A., and Iqbal, M. (2000). Some Strategic Suggestions for Islamic Banking in the 21st Century. Review of Islamic Economics, 9.

- Onakoya, A., and Onakoya, A. (2013). The performance of Traditional and Islamic banks in the United Kingdom: A comparative analysis. from https://www.academia.edu/3180579/The_Performance_of_Traditional_and_Islamic_Banks_in_the United Kingdom A Comparative Analysis.

- Oqool, M., Okab, R., and Bashayreh, M. (2014). Financial Islamic Banking Development and Economic Growth: A Case Study of Jordan. International Journal of Economics and Finance , 6(3).

- Page, J., and Steel, W. (1984).Small enterprises development: economic issues from African experience. World bank. Technical paper. Washington D.C.

- $\quad$ Rezaul, K., and Osada, M. (1998). Dropping Out: An Emerging Factor in the Success of Microcredit-based 
Poverty Alleviation Programs. The Developing Economies,36(3).

- Sarwer, S., Ramzan, M., and Ahmad, W. (2013). Does Islamic Banking System Contributes to Economy Development. Global Journal of Management and Business Research, 13(2).

- Siddiqui, M. (2002). Comparative Advantages of Islamic Banking and Finance, viewed 24/01/2005, http://www.siddiqi.com/mns/Advantages.html.

- Siddiqui, M. (2008). Current Financial Crisis and Islamic Economics. Mimeo. Retrieved from http://aawad.kau.edu.sa/Files/121/Researches/55495_25818.pdf.

- Solé, J. (2008). Introducing Islamic Banks into Conventional Banking Systems. Journal of Islamic Economics, Banking and finance. Retrieved from http://www.ibtra.com/pdf/journal/v4_n2_article1.pdf.

- Wrenn, E. (2007). Perceptions of the Impact of Microfinance on Livelihood Security, Research and Perspectives on Development Practice. Kimmage DSC, Development Studies Centre. Ireland. 